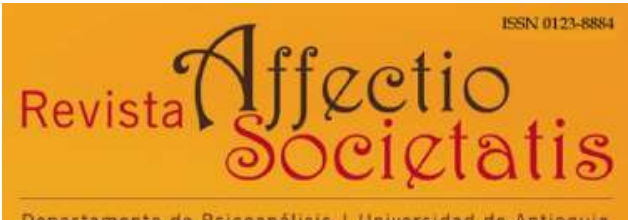

Departamento de Psicoanálisis / Universidad de Antioquia

Revista Affectio Societatis

Departamento de Psicoanálisis

Universidad de Antioquia

revistaaffectiosocietatis@udea.edu.co

ISSN (versión electrónica): 0123-8884

Colombia

2020

Manuel Fernández Alcántara, Cayetana Correa, Carolina Laynez Rubio, Juan F. Navas, Christian E. Salas, Francisco Cruz Quintana

The therapeutic role of signifier opposition and fort-da in the treatment of a child diagnosed with autism spectrum disorder (ASD): a case report

Revista Affectio Societatis, Vol. 17, N. ${ }^{\circ} 32$, enero-junio de 2020

Art. \# 4 (pp. 86-104)

Departamento de Psicoanálisis, Universidad de Antioquia

Medellín, Colombia 


\title{
THE THERAPEUTIC ROLE OF SIGNIFIER OPPOSITION AND FORT-DA IN THE TREATMENT OF A CHILD DIAGNOSED WITH AUTISM SPECTRUM DISORDER (ASD): A CASE REPORT ${ }^{1}$
}

\author{
Manuel Fernández Alcántara² \\ Universidad de Alicante, España \\ mfernandeza@ua.es \\ ORCID: 0000-0002-3481-8156
}

Cayetana Correa ${ }^{3}$ Psycho-Neurological Center, España cayetanacorrea@gmail.com ORCID: 0000-003-4279-6548

1 Caso de un niño de 2 años diagnosticado con trastorno del espectro autista que realizó un tratamiento psicoanalítico de orientación lacaniana. Se aplicó el paradigma del fort-da en las tres áreas dónde el paciente presentaba mayor sintomatología: la intención comunicativa, el juego simbólico y el apego materno. Creemos que esta investigación puede ser útil tanto a clínicos como a psicoanalistas puesto que se ha puesto especial énfasis en describir los aspectos operativos de la intervención psicoanalítica, así como la lógica utilizada a partir de las directrices de Freud y Lacan.

2 Doctor en Psicología por la Universidad de Granada y Profesor Ayudante Doctor del Departamento de Psicología de la Salud de la Universidad de Alicante. Miembro del grupo de investigación CTS-436 "Aspectos Psicosociales y Transculturales de la Salud y la Enfermedad". Miembro fundador de la Sociedad Nacional de Investigación en Fin de Vida. Coordinador del Máster en Envejecimiento Activo y Salud de la Universidad de Alicante.

3 Doctora en Psicología por la Universidad de Granada. Psicóloga experta en Neuropsicología. Psicóloga general sanitaria. Psicoanalista. Miembro fundador del gabinete multidisciplinar Anuda. Realiza sus investigaciones en el campo del neurodesarrollo y de los problemas de aprendizaje. 
Carolina Laynez Rubio ${ }^{4}$

San Cecilio Clinical Hospital, España

laynezrubio@gmail.com

ORCID: https://orcid.org/0000-0003-2447-1723

Juan F. Navas ${ }^{5}$

Universidad Autónoma de Madrid, España

juan.navas@uam.es

ORCID: 0000-0002-9521-6642

Christian E. Salas ${ }^{6}$

Universidad Diego Portales, Chile

salasriquelme@gmail.com

ORCID: https://orcid.org/0000-0001-7700-1341

Francisco Cruz Quintana ${ }^{7}$

Universidad de Granada, España

fcruz@ugr.es

ORCID: 0000-0001-9805-5939

DOI: 10.17533/udea.affs.v17n32a04

4 Doctora en Psicología por la Universidad de Granada. Psicoanalista. Psicóloga general sanitaria. Psicóloga Clínica en el Hospital Universitario Campus de la Salud de Granada, Granada.

5 Doctor en Psicología por la Universidad de Granada. Contratado post-doctoral en la Universidad Autónoma de Madrid, España. Sus áreas de interés incluyen el trabajo en juego patológico, las adicciones, o el uso de la entrevista motivacional como herramienta terapéutica.

6 Doctor en Psicología por la Universidad de Bangor (Reino Unido). Neuropsicólogo clínico y psicoterapeuta de orientación psicoanalítica. Director del Diploma en Rehabilitación Neuropsicológica del Adulto y Coordinador de la Unidad de Neuropsicología Clínica. Facultad de Psicología, Universidad Diego Portales (Chile).

7 Doctor en Psicología por la Universidad de Granada y Catedrático del Dpto. de Personalidad, Evaluación y Tratamiento Psicológico de la Universidad de Granada. Psicoanalista. Es director del grupo de investigación CTS-436 "Aspectos Psicosociales y Transculturales de la Salud y la Enfermedad" e investigador del Centro de Investigación Mente, Cerebro y Comportamiento. Profesor responsable 


\section{Abstract}

From a Lacanian perspective, interventions in cases of autism should aim to introduce a symbolic absence that mobilizes the circuit of desire. The case of a 2-year-old boy (Q) diagnosed with autism spectrum disorder attending to Lacanian treatment is presented. The fort-da paradigm (using a pair of signifiers to represent the presence-absence) was introduced to address problems with attachment, communicative intention, and symbolic game. After treatment $Q$ learned how to use his own language and symbolic game to regulate and express anxiety and other emotions in the absence of his mother.

Keywords: autism, psychoanalysis, fort-da, Lacan, attachment.

\section{EL PAPEL TERAPÉUTICO DE LA OPOSICIÓN SIGNIFICANTE Y EL FORT-DA EN EL TRATAMIENTO DE UN NIÑO DIAGNOSTICADO CON TRASTORNO DEL ESPECTRO AUTISTA (TEA): UN ESTUDIO DE CASO ${ }^{1}$}

\section{Resumen}

Desde una perspectiva lacaniana, las intervenciones en casos de autismo deberían apuntar a introducir una ausencia simbólica que movilice el circuito del deseo. Se presenta el caso de un niño de dos años (Q) diagnosticado con trastorno del espectro autista y que asistía a un tratamiento lacaniano. Se introdujo el paradigma del fort-da (que usa un par de significantes para representar la presencia-ausencia) para abordar los problemas de vínculo, intención comunicativa y juego simbólico. Después del tratamiento, $Q$ aprendió a usar su propio lenguaje y juego simbólico para regular y expresar la ansiedad y otras emociones en ausencia de su madre.

Palabras clave: autismo, psicoanálisis, fort-da, Lacan, vínculo.

de la asignatura Clínica Psicoanalítica en la Universidad de Granada. Miembro fundador de la Sociedad Andaluza de Neuropsicología y de la Sociedad Nacional de Investigación en Fin de Vida y miembro de la Comisión de Acreditación en Psico-oncología y Cuidados Paliativos del Consejo General de Psicología de España. 


\section{LE RÔLE THÉRAPEUTIQUE DE L'OPPOSITION DU SIGNIFIANT ET LE FORT-DA DANS LE TRAITEMENT D'UN ENFANT DIAGNOSTIQUÉ TROUBLE DU SPECTRE DE L'AUTISME (TSA) : UN RAPPORT DE CAS'}

\section{Résumé}

Selon une approche lacanienne, les interventions dans des cas d'autisme devraient viser l'introduction d'une absence symbolique qui mobilise le circuit du désir. L'article présente le cas d'un enfant de deux ans $(\mathrm{Q})$ diagnostiqué trouble du spectre de l'autisme suivant un traitement lacanien. Le paradigme fort-da (utilisant une paire de signifiants pour représenter la présence-absence) a été intro- duit pour traiter des problèmes liés à l'attachement, l'intention communicative et le jeu symbolique. Après le traitement $\mathrm{Q}$ a appris comment utiliser son propre langage et le jeu symbolique pour réguler et exprimer l'anxiété et d'autres émotions face à l'absence de sa mère.

Mots-clés : autisme, psychanalyse, fort-da, Lacan, attachement. 


\section{Introduction}

Autism spectrum disorder (ASD) is characterized by socio-communicative deficits and repetitive and restricted patterns of interests, activities, and behaviors (APA, 2013). Research initiated in the 1970's linked ASD symptoms to abnormal neurological development, mainly characterized by deficits in social cognition (see Singletary, 2015 for a recent review of the neural basis of ASD and their relation to the psychoanalytic paradigm; and Vivanti, 2017 for a theoretical discussion about current models of intervention in ASD).

\section{A psychoanalytic perspective on ASD}

Psychoanalytic research from diverse theoretical paradigms has stressed the relevance of distinct elements in understanding and treating individuals with ASD. Some of these are the organization of subjectivity, mentalization-symbolization processes, the role of transference and countertransference, and the formation of social bonds (Bion, 1984; Durban, 2014; Mahler, 1979; Meltzer, 1975; Rhode, 2015; Tustin, 1972; Viloca \& Alcácer, 2014). In the present article we will particularly focus on the theoretical and technical interventions in ASD from a lacanian perspective.

In their classic reports, Robert and Rosaline Lefort (1998, 2003) propose that autism is an independent clinical structure, at the same level of psychosis, neurosis or perversion. This structure is characterized by (a) a disruption of the enunciation (derived from a lack of primordial identification) and (b) the use of autistics objects (Maleval 1998, 2009). The first characteristic is related to a lack of identification that prevents the person with ASD from being integrated in language- to speak about himself and generate his/her own discourse. The person with ASD is not external to language, but included in it as a signifier that has lost its main characteristic: to be in relationship with other signifiers. Thus, the person with ASD stays isolated, without the opportunity to access symbolic representations of oneself or the external world (Laurent, 2008, 2013). Language in autism is fixed, a real (réel) with no semantic value; thus, not allowing a Subject to emerge. According to Lacan (1964), the subject is created through a 
language operation, namely, by the introduction in the symbolic field through the desire of the Other. This movement allows the formation of a personal mark from where one can speak. Being introduced in language through a symbolic representation separates the individual from the immediate presence, generating a place from where he/she can communicate with others (Gutiérrez-Peláez, 2014).

Regarding the second characteristic, the person with ASD, overwhelmed by perceptions and stimuli that he/ she cannot structure, uses objects (autistic objects) as a protection and defense system (Pimenta, Santiago, \& Santiago, 2016; Tustin, 1992). Usually these objects are located outside of the body, are not different from it, and function as a substitution of the symbolic Other. This idea could explain why people with ASD prematurely adhere to numbers or letters (fixed symbols) as a way to order and restrict their world, using objects.

\section{Fort-da as a symbolic mechanism}

The use of autistic objects is associated with a repetitive behavior that does not need to be accompanied by a symbolic component. Nevertheless, repetition can have an important symbolic quality in the fortda situation (Freud, 2006/1920). The fort-da is an active mechanism aimed to manage anxiety through the use of a signifier (presenceabsence) and an object. The latter has the function of being the substitute (a transitional object) of the first object, the mother (Winnicott, 1975). Freud (2006/1920) described the fort-da mechanism using a game where a child played with an object in order to manage negative feelings associated with the absence of his mother. The child used a bobbin connected to a thread, which he repeatedly tossed away, making it disappear and then re-appear. A pair of words that the child related to the presence or the absence of the bobbin, respectively, accompanied this action: fort and da. Lacan (1964) considered the fort-da as the core mechanism that expresses how the subject of language is constituted in the experience of the loss of the first object of satisfaction (the mother).

Maleval and Grollier (2015) state that the experience of signifier opposition (presence-absence) that characterizes the fort-da can re- 
duce the anxiety of the child. It creates a new subjective experience that re-organizes and modifies the child's perception of the world, allowing more flexibility and richness. The fort-da has been previously used in clinical psychoanalysis to treat anxiety symptoms generated by attachment problems or separation anxiety (Oyarce-Cadiz \& Passone, 2016). Our hypothesis is that fort-da can also be used to address symptoms in patients with ASD, who have a need for symbolic elements to develop his own subjective discourse.

The objective of the present case study is to present the clinical case of a child diagnosed with ASD (called Q). We used the fort-da as a therapeutic tool to address the child's maternal attachment anxiety, communicative intention deficits, and lack of symbolic game.

\section{Case Presentation}

Q's parents were referred to treatment by a pediatrician because of symptoms consistent with ASD. Q was a physically healthy 2-yearold boy without peri or postnatal problems. Although he had an affective bond with both of his parents, he had attachment problems indicated by great anxiety when separated from his mother. $Q$ became extremely anxious when his mother had to leave.

In addition, he showed impaired communication skills. He knew all numbers and letters, could draw them in the air with his finger, and spelled the names of objects when he pointed at them; however, he did not say "yes"; and he pronounced "no" in a peculiar way (using the phoneme "mo"). He could understand commands although he did not answer questions and did not express opinions or desires. $Q$ had difficulty maintaining a steady gaze, although he seemed comfortable with physical touch and liked to be tickled, kissed, or hugged. When he was not able to attain what he wanted, he reacted with intense tantrums. Moreover, the development of symbolic game also appeared stalled. $Q$ rarely played with his one year older brother and when he did, he needed periods of isolation in order to self-regulate (see supplemental material for other characteristics pre-treatment). 
Considering these symptoms and the information provided by Q's parents, the analyst hypothesized that $Q$ had an autistic structure. Q's parents agreed to begin a psychodynamic treatment to manage these symptoms. Informed written consent was obtained from Q's parents for the publication of the present case report. In addition, the study was approved by the Ethical Committee of Clinical Research of the University (Reference: PI-10/02735).

\section{Results}

The analyst hypothesized that Q's symptoms were caused by a potential interruption of his development linked to a maternal absence. This was experienced as a real (réel) that $Q$ could not symbolize, having a "muteness" effect (Lacan, 1964). The analyst applied an intervention based in fort-da (presence-absence) in the three main areas where symbolic deficits were observed: (a) maternal attachment, (b) communicative intention, and (c) symbolic game.

During the first four months of treatment sessions took place twice a week. After that, the numbers of sessions was reduced to one per week. After one year, these sessions were alternated with speech therapy sessions. Currently -four years after the beginning of treatment- a monthly follow up is maintained.

\section{Maternal Attachment}

An intervention using the for-da logic was implemented as follows. During the first sessions, Q's mother stayed with him. This setting was maintained until $Q$ incorporated some symbolic elements, and the transference with the analyst was established. Considering his problems with maternal separation, instead of the mother, the analyst and $Q$ were the ones that left the consultation room. $Q$ was told that his mother was going to stay in the room next door. When they were leaving the consultation room, the analyst always asked Q: "where is mom?" (absence). Then, both checked that Q's mother was still in the room next door and had not disappeared (presence). The analyst 
progressively increased the time interval before the checking, and she introduced comments such us "let's go to show it to mom!" while they were away. Parents were encouraged to repeat this dynamic at home, and to encourage discussion between $Q$ and his father when the mother was not present: "where is mom?", "then, we will show it to mom later!". After two sessions and training at home, $Q$ was able to stay in the consulting room on his own and his mother did not have to wait outside (see Table 1, first row).

Through this change, $\mathrm{Q}$ could become an active agent in relation to the separation from his mother (Freud, 2006/1920). The analyst used the fort-da to develop questions regarding where the mother was or what they will do in the future. The coming and going from the consultation room appeared to help $\mathrm{Q}$ in becoming an active subject regarding his anxiety. The intervention succeeded in creating a differentiated space for $Q$ from where his language and games could develop.

Table 1. Example quotes from exchanges during treatment in relation to attachment, communicative intention and symbolic game areas.

\begin{tabular}{|c|c|}
\hline Attachment & $\begin{array}{l}\text { Fragment 1. Speaking about mom. } \\
\text { Analyst: "Where is mom when you are here?" } \\
\text { Q: "Shopping, having a coffee with dad". } \\
\text { Analyst: "For sure. Then she will come back to pick you up..., and, what are } \\
\text { you going to do? } \\
\text { Q: "We go dad and brother to the park, and mom to the gym, and then to } \\
\text { home" }\end{array}$ \\
\hline $\begin{array}{l}\text { Communicative } \\
\text { intention } \\
\text { First } \\
\text { communicative } \\
\text { events }\end{array}$ & $\begin{array}{l}\text { Fragment 1. The first proper event that } Q \text { was able to talk about. } \\
\text { "Grandfather... happy birthday to you, happy birthday to you... (Singing } \\
\text { the whole Happy Birthday song)" } \\
\text { Fragment 2. On one occasion in which he did not want to attend therapy. } \\
\text { Q: "[name of second author], no, Q angry". }\end{array}$ \\
\hline $\begin{array}{l}\text { Communicative } \\
\text { intention } \\
\text { Session endings }\end{array}$ & $\begin{array}{l}\text { Fragment 1. When he wanted to leave the session. } \\
\text { Q: "Good bye Poco yo*; see you soon". } \\
\text { Analyst: "Ok, I think you would like to go; but this is what Poco yo says. What } \\
\text { does Q say, what do you say?" } \\
\text { Fragment 1. After some time, when he wanted to leave the session. } \\
\text { Q: "let's go to tidy up, to keep everything in its place"** }\end{array}$ \\
\hline
\end{tabular}




\begin{tabular}{|c|c|}
\hline $\begin{array}{l}\text { Communicative } \\
\text { intention } \\
\text { Tantrums }\end{array}$ & $\begin{array}{l}\text { Fragment 1. After a tantrum. } \\
\text { Analyst: "You are very upset, what's going on?" } \\
\text { Fragment 2. 20-30 minutes after a difficult tantrum; Q proposed to play. } \\
\text { C: "C upset no, Q happy!" } \\
\text { Analyst: "Well, C. was a little bit upset, because I don't like you shouting at me; } \\
\text { you have to calm down, and when you calm down l'd love to play with you". } \\
\text { Fragment 3. He was playing during a session and suddenly wanted to go be } \\
\text { with his mother who was in the waiting room. He stood up and opened the door. } \\
\text { Analyst: (blocking the door to prevent Q from leaving; Q cried desperately) "Tell } \\
\text { me what you want! I don't know what you want. You can't go alone whenever } \\
\text { you feel like it; just tell me what you want". } \\
\text { Q: "Mom" } \\
\text { On such occasions, Q's mother was included in the session, because Q had } \\
\text { been capable to express a desire, while accepting certain limits. } \\
\text { Analyst: "You can't leave the room like this, if you want to see mom, we will call } \\
\text { her". }\end{array}$ \\
\hline Symbolic game & $\begin{array}{l}\text { Fragment 1- Sentences of Q reflecting Q's sexual investigation with the puzzle. } \\
\text { "The boy has a penis" } \\
\text { "Q has a penis" } \\
\text { "Dad has a penis" } \\
\text { "Girls do not have a penis" }\end{array}$ \\
\hline & $\begin{array}{l}\text { "Mom does not have a penis" } \\
\text { "C. does not have a penis" } \\
\text { "The boys have penises, the girls don't, the girls have vaginas *** } \\
\text { Fragment } 2 \text { - Playing with the puzzle. } \\
\text { Analyst: "What is the girl's name? } \\
\text { Q: "feet, hands, legs, fingers". } \\
\text { Analyst: "Ok, we all have these, they are things that we all have, but, what is } \\
\text { the girl's name?" }\end{array}$ \\
\hline
\end{tabular}

Note. ${ }^{*}$ Poco yo is the name of one of his favorite characters. ${ }^{* *}$ A sentence that Q's teacher always says. ${ }^{* *}$ A quote from the puzzle.

\section{Communicative intention}

The fort-da was employed in this area to help $Q$ to develop his own discourse as a desiring subject. For instance, $Q$ had to choose between two possibilities (two different toys) and name the one he preferred before beginning to play. This intervention allowed $Q$ to progressi- 
vely separate from a dichotomous language (Yes-No). Subsequently, the analyst introduced games and pictures from books and formulated more complex questions that allowed $Q$ to express his own opinions ("do you like it?", "what is your favorite color?", "what is that kid doing?"). In table 1 (second row) we present some examples of communication exchanges between $Q$ and the analyst. Gradually, the spontaneous expressions became more frequent and he began to copy sentences from cartoons, his family, and school (see Table 1, third row).

Improvements in communicative intention could reflect a process where $Q$ progressively separated from the words of others and began to use his own words. With the emergence of intentional communication and spontaneous speech $Q$ became more capable of using words to regulate his behavior. Tantrums could now be regulated by introducing verbal symbolic elements which helped putting $Q^{\prime}$ s emotional states into words (see Table 1, fourth row). During sessions, when $Q$ had an intense tantrum the analyst encouraged him to use words to express his feelings or what he wanted, during and after the tantrum. The analyst also proposed to Q's parents to implement this strategy at home (see Table 1, fourth row). This intervention could strengthen Q's symbolic functions allowing him to postpone his desires and regulate his symptoms.

\section{Symbolic game}

Q's initial games were characterized by rigidity, lack of content, and difficulty in interacting with a partenaire. The analyst took an active position and introduced herself in the games (as a subject of desire). For instance, Q's first game was to pile up blocks in order to build towers. The analyst joined the game by destroying each tower. $Q$ immediately tried to stack them again, but the analyst stopped him: "now it is my turn". Q was extremely displeased with such variation in his game. However, after the analyst had built a tower, she said to Q: "now it is your turn". The introduction of a pause and turns could allow two signifiers to operate during the session and coordinate the interaction in a new light: "now you play-now I play". The analyst introduced modifications progressively, but considering the emergence 
of repetitions in Q's behavior, so he would not be overwhelmed by the lack of structure. One session later, $Q$ began to imitate the analyst by suggesting to her the previously learnt interactive script: "who's turn is it?". Gradually, Q began to integrate pronouns (mine-yours), suggesting a progressive interiorization of the dialectic dynamic. He also became interested in playing with cars in a garage. It was in this moment when truly symbolic game emerged in Q's behavior: in his narrative, cars represented members of his family (according to their size) who became mischievous characters, hid from one another, or went to family trips.

Another example of the development of symbolic game was related to the use of puzzles. Q's favorite puzzle was that of a naked girl and a naked boy, in which the names of body parts were shown. The analyst introduced the subjective experience of $Q$ by asking him about the girl's name (see Table 1, fifth row), but initially he did not answer. After four sessions in which $Q$ continued without responding, the analyst proposed several names. He always said "No" until one day he came up with a name of his own (the name of one of his schoolmates). From that moment, the analyst began to ask where different body parts were (of schoolmates', the analyst's, and Q's own body). Afterwards, the same questions were asked using the puzzle of the boy, and $Q$ gave the boy its own name. This fact reflected a relevant symbolic leap, which allowed working with identifications and sexual difference. Thereby, $Q$ ended up calling the boy " $Q$ the toy", thus, differentiating it from himself.

\section{Current state}

A detailed description of the main behavioral changes observed in $\mathrm{Q}$ is available in Tables 2 and 3 . At the present time $Q$ is capable of using grammatically-correct complex sentences in which he expresses desires, feelings, and opinions. Besides, he can joke and even enjoy double-meanings and irony. $Q$ is able to share with others what he does at school and talks about things that annoy him. Since the beginning of therapy, his game has become more complex, often including human figures and choosing a wide range of stories. Nevertheless, Q's games are still considerably repetitive and rigid. 
Q has presented some positive changes also outside the consulting room. He is more capable to interact with peers and the need for periods of isolation has decreased. In relation to attachment issues, a significant improvement has been observed. $Q$ can now separate from his parents for relative long periods of time without showing signs of anxiety. In general terms, although there are symptoms that persist like rigidity and behavioral perseveration, $Q$ shows an improved adjustment in several domains of his family and social life.

Table 2. A schema of the process of change in the three main areas addressed during treatment.

\begin{tabular}{|c|c|}
\hline Main areas & Changes during treatment \\
\hline Communicative intention & $\begin{array}{l}\text { - Yes-No. } \\
\text { - Proposal of games and drawing. } \\
\text { - Proto-conversation (Other's words). } \\
\text { - First simple opinions. }\end{array}$ \\
\hline Symbolic game & $\begin{array}{l}\text { - Introduction of You-Me. } \\
\text { - Proposal to narrate what has happened. } \\
\text { - Small changes with respect to the fixed game. } \\
\text { - Development of interest in playing other games. }\end{array}$ \\
\hline Separation anguish & $\begin{array}{l}\text { - Presence-Absence-Presence } \\
\text { - Proposition of the mother's presence and the child's absence. } \\
\text { - Introduction of the word during absence, as well as the desire of pres- } \\
\text { ence within a temporal limit. } \\
\text { - Development of the capacity to separate from his mother both during } \\
\text { clinical sessions and at home. }\end{array}$ \\
\hline
\end{tabular}

Table 3. Summary of Q's main symptoms and characteristics pre-treatment and associated changes post-treatment.

\begin{tabular}{|c|c|c|}
\hline Domain & Pre-treatment & Post-treatment \\
\hline Feeding & $\begin{array}{l}\text { - Restricted to crushed food. } \\
\text { - Disgusted by certain textures. }\end{array}$ & $\begin{array}{l}\text { - Includes solid food. } \\
\text { - Tastes practically all types of textures. }\end{array}$ \\
\hline Language & $\begin{array}{l}\text { - Delay in acquisition: } \\
\text { Babbling. } \\
\text { No communicative intention. } \\
\text {-Short language spam: Mo/Dad/ } \\
\text { Mom. }\end{array}$ & $\begin{array}{l}\text { - Delay in production. } \\
\text { - Structured speech. } \\
\text { - Communicative intention. } \\
\text { - Use of sentences of more than } 7 \text { words. }\end{array}$ \\
\hline Attachment & $\begin{array}{l}\text { - Separation anguish. } \\
\text { - Pleasure from physical touch. } \\
\text { - No steady gaze. } \\
\text { - Need for isolation during games } \\
\text { with peers. }\end{array}$ & $\begin{array}{l}\text { - No separation anguish. } \\
\text { - Pleasure from physical touch. } \\
\text { - Steady gaze. } \\
\text { - Actively looks for interaction with others. }\end{array}$ \\
\hline
\end{tabular}




\begin{tabular}{|c|c|c|}
\hline Domain & Pre-treatment & Post-treatment \\
\hline & $\begin{array}{l}\text { - Emotional expression restricted to } \\
\text { facial movements. }\end{array}$ & $\begin{array}{l}\text { - Decrease in the frequency of isolation } \\
\text { periods. } \\
\text { - Both oral and facial emotional } \\
\text { expressions. }\end{array}$ \\
\hline Obsessions & $\begin{array}{l}\text { - Fixation with the mother's breast } \\
\text { and closed doors. } \\
\text { - No mannerisms. } \\
\text { - No comfort objects. }\end{array}$ & $\begin{array}{l}\text {-Does not look for his mother's breast. } \\
\text { - Does not show a preference for closed or } \\
\text { open doors. }\end{array}$ \\
\hline Intelligence & $\begin{array}{l}\text { - Good ability to imitate. } \\
\text { - Knows letters and numbers. } \\
\text { - Good gross motor abilities. } \\
\text { - Interest in puzzles. }\end{array}$ & $\begin{array}{l}\text { - Good ability to imitate and to perform } \\
\text { actions following oral instructions. } \\
\text { - Knows letters and numbers, and can write. } \\
\text { - Good gross motor abilities. } \\
\text { - Interest in puzzles, costumes, and } \\
\text { symbolic games. } \\
\text { - Explores the environment. } \\
\text { - Normal acquisition of developmental } \\
\text { milestones (excluding language). }\end{array}$ \\
\hline
\end{tabular}

\section{Discussion}

The current case report illustrates the usefulness of the fort-da in a case of ASD. The fort-da was employed as a mechanism for modifying the subjective position of $Q$ and creating an empty space that helps him leave his silence, repetition, and anguish. The continuous experience of a pair of signifiers (presence-absence) produced calmness in the child and allowed him to interact dialectically with others around him. He could replace the absence with words, plans, symbolic games, and the interiorization of his mother's presence (Lacan, 1958). Although the fort-da has been used previously in the psychoanalytic approach to ASD (Lefort \& Lefort, 1998; Maleval \& Grollier, 2015), the novelty of the current case lies in the complete description of how this concept was adapted to target diverse symptomatology.

The fort-da was applied in an inverse manner, taking into account that $Q$ was the one absent and, accompanied by the analyst, transformed the real absence of his mother in a symbolic lack. It can be hypothesized that after the fort-da, the child could obtain a reserve of libido, that allowed him to retain some presence of the Other even in the cases when it is absent (Laurent, 2008). 
The fort-da was also applied when $Q$ had to choose between the first two signifiers that he formulated (Yes-No) and with the use of pauses during games, that facilitated the emergence of a distinction between I and You (Vecchiato, Sacchi, Simonelli \& Purgato, 2016). In all the cases there is a loss that allows the subject to change his previous position to establish a social bond with the Other (LaynezRubio, 2012; Thurin, Thurin, Cohen, \& Falissard, 2014). These three aspects tied together could make up a new psychic reality for the child (Lacan, 1964).

Through this new psychic reality, we can pinpoint one of the turning points in the treatment: the moment when $Q$ discovered that our I ( $j e)$ is related to the subjective quality that gives us our personal name. $\mathrm{Q}$ gave his own name to the toy, although he added " $\mathrm{Q}$ the toy", in order to differentiate it from him: $Q$ is the one that is alive and can speak. This important progress in his sense of identity was related to the identification of differences between alive and dead, between sexes, and between the I-My and the You-Yours. This process showed how $Q$ could begin to master his own language through the fort-da process.

The current research has some important limitations. First, we used qualitative measures of the potential effects of the treatment. Future studies should include quantitative measures to assess changes after the intervention (see Cornet \& Vanheule, 2017, for a recent study that assess the dimensions of communication, autonomy, motor function and socialization in a sample of children diagnosed with autism, before and after a two-year lacanian psychodynamic treatment). Second, due to the design of the study, we are not able to disentangle if Q's improvements are directly related to the psychoanalytic treatment or to other parallel interventions (i.e., speech sessions). This limitation, however, needs to be put in context. Rehabilitation interventions are multi-componential in nature since patients with acquired or developmental neurological conditions have both cognitive and psychological needs that cannot be separated. Evidence regarding the effectiveness of holistic Neuropsychological programs, which have combined cognitive and psychoanalytic frameworks to address neuropsychological problems in people with acquired brain damage, 
supports this idea (Prigatano, 1986, 1999, 2008; Prigatano \& Salas, 2017). In relation to ASD, Vecchiato et al. (2016) have also reported the use of psychodynamic therapy in the context of multidisciplinary work, including elements from both approaches as well as psychoeducation, psychomotor training and speech therapy. Despite these methodological limitations, this study could be considered as a first step in exploring the theoretical and clinical usefulness of the fortda in ASD, thus offering general guidelines on how to incorporate a Lacanian perspective in the multidisciplinary treatment of a child with ASD.

In conclusion, the fort-da and the use of signifier opposition seem to be a useful instrument in the treatment of ASD symptoms from a psychoanalytical perspective. Considering the case of $Q$, key therapeutic elements could be considered as relevant in the treatment's success, such as the development of a safe therapeutic atmosphere where the patient-analyst interaction can potentiate the child's flexibility, where it is possible to attend to family dynamics and promote their participation in the treatment. The logic of the fort-da considers the active role of the analyst, who can mobilize the fixed subject and open the circuit of desire. The current approach that outlines the emotional and subjective development of the child can be used as part of an integral intervention aimed to address the distinct problems in children with ASD and their families.

\section{Acknowledgements}

We thank Dr. Dafina Petrova and Antonio Jesús Gracia Rodríguez for assistance with the English version of the manuscript.

\section{References}

American Psychological Association (APA). (2013). Diagnostic and Statistical Manual of Mental Disorders (DSM-5®). American Psychiatric Association. 
Bion, W. R. (1984). Elements of psychoanalysis. London, U.K.: Karnac Books. Charman, T., Swettenham, J., Baron-Cohen, S., Cox, A., Baird, G., \& Drew, A. (1997). Infants with Autism: an Investigation of Empathy, Pretend Play, Joint Attention, and Imitation. Developmental Psychology, 33(5), 781.

Cornet, J. P., \& Vanheule, S. (2017). Évaluation de la prise en charge institutionnelle d'enfants atteints d'un trouble envahissant du développement [Evaluation of a Therapy in Institutional Settings for Children with Pervasive Developmental Disorder]. L'Évolution Psychiatrique, 82(3), 687-702.

Durban, J. (2014). Despair and Hope: on Some Varieties of Countertransference and Enactment in the Psychoanalysis of ASD (Autistic Spectrum Disorder) Children. Journal of Child Psychotherapy, 40, 187-200.

Freud, S. (2006/1920). Más allá del principio del placer [Beyond the Pleasure Principle]. In Obras completas [The Complete Works of Sigmund Freud]. Madrid, España: Biblioteca Nueva.

Gutiérrez-Peláez, M. (2014). El psicoanálisis de orientación lacaniana en el tratamiento del autismo [The Psychoanalysis of Lacanian Orientation in the Treatment of Autism]. Affectio Societatis, 11(21), 1-8. Retrieved from: http:/ / aprendeenlinea.udea.edu.co/revistas/index.php/affectiosocietatis.

Lacan, J. (1958). La dirección de la cura y los principios de su poder [The Direction of the Treatment and the Principles of its Power]. In: Escritos I [Writings I]. México: Siglo XXI Editores.

Lacan, J. (1964). Seminario 11. Los cuatro conceptos fundamentales del psicoanálisis [Seminar 11. The Four Fundamental Concepts of Psycho-analysis]. Buenos Aires, Argentina: Paidós.

Lacan, J. (1965). Le Séminaire 12. Problèmes cruciaux pour la psychanalyse [Seminar 12. Crucial Problems for Psychoanalysis]. Paris, France: Editions de l' Association Freudienne Internationnale.

Laurent, E. (2008). La cifra del autismo [The Digit of Autism]. Le Nouvel Âne, 8. Available in http://virtualia.eol.org.ar/023/template.asp?Accionlacaniana/La-cifra-del-autismo.html 08.

Laurent, E. (2013). La batalla del autismo: de la clínica a la política [The Struggle of Autism: from Treatment to Politics]. Buenos Aires, Argentina: Grama Ediciones.

Laynez-Rubio, C. (2012). Silencio y vínculo social [Silence and Social Bond]. Revista Letrahora, 11. Available in http://letrahora.com/index. php/2015/12/28/silencio-y-vinculo-social.

Lefort, R., \& Lefort, R. (1998). Le symptôme charlatan [The Speaking Symptom]. Paris, France: Seuil.

Lefort, R., \& Lefort, R. (2003). La distinction de l'autisme [The Distinction of Autism]. Paris, France: Seuil. 
Mahler, M., (1979). The Selected Papers of M. S. Mahler. Volume I. New York, U.E.: Janson Aronson Press.

Maleval, J. C. (1998). De l'autisme de Kanner au syndrome d'Asperger [From Kanner's Autism to the Asperger syndrome], L'Évolution Psychiatrique, 63, 293-309.

Maleval, J. C. (2009). L'autiste et sa viox [The Autist and his Voice]. Paris, France: Seuil.

Maleval, J. C., \& Grollier, M. (2015). Extension du spectre de l'autisme [Expansion of the Autism Spectrum]. L'Évolution Psychiatrique, 80, 764-781.

Meltzer, D. (1975). Explorations in Autism: A Psycho-analytical Study. London, U.K.: Karnac Books.

Oyarce-Cadiz, D., \& Passone, S. M. (2016). Intersubjective Approach to Separation Anxiety and their Therapeutic Implications. Affectio Societatis, 13(24), 13-25. Retrieved from http://aprendeenlinea.udea.edu.co/revistas/index.php/affectiosocietatis.

Pimenta, P. R., Santiago, J., \& Santiago, A. L. (2016). Harmfulness of the Autistic Object to its Indispensability for Autism Clinically in Psychoanalysis. Ágora: Estudos em Teoria Psicanalítica, 19, 339-356. Retrieved from http:/ / dx.doi.org/10.1590/S1516-14982016002013

Prigatano, G. P. (1986). Neuropsychological Rehabilitation after Brain Injury. Oklahoma, U.S.: Johns Hopkins University Press.

Prigatano, G. P. (1999). Principles of Neuropsychological Rehabilitation. New York, U.S.: Oxford University Press.

Prigatano, G. P. (2008). Neuropsychological Rehabilitation and Psychodynamic Psychotherapy, in Textbook of Clinical Neuropsychology (pp. 985-995), (J. E. Morgan \& J. H. Ricker eds.), London, U.K.: Taylor \& Francis.

Prigatano, G. P., \& Salas, C. E. (2017). Psychodynamic Psychotherapy after Severe Traumatic Brain Injury. In Neurobehavioural Disability and Social Handicap Following Traumatic Brain Injury (pp. 188-201), (T. M. McMillan \& R. L. Wood, eds.). New York, U.S.: Psychology Press.

Rhode, M. (2015). 'Paralysed Associations': Countertransference Difficulties in Recognising Meaning in the Treatment of Children on the Autistic Spectrum. Journal of Child Psychotherapy, 41, 218-230.

Singletary, W. M. (2015). An Integrative Model of Autism Spectrum Disorder: ASD as a Neurobiological Disorder of Experienced Environmental Deprivation, Early Life Stress and Allostatic Overload. Neuropsychoanalysis, 17(2), 81-119.

Thurin, J. M., Thurin, M., Cohen, D., \& Falissard, B. (2014). Approches psychothérapiques de l'autisme. Résultats préliminaires à partir de 50 études intensives de cas [Psychotherapeutic Approaches for Autism. Pre- 
liminary Results from 50 Intensive Case Studies]. Neuropsychiatrie de l'enfance et de l'adolescence, 62(2), 102-118.

Tustin, F. (1972). Autisme et psychose de l'enfant [Autism and Infant Psychosis]. Paris, France: Seuil.

Tustin. F. (1992). Autisme et protection [Autism and Protection]. Paris, France: Seuil.

Vecchiato, M., Sacchi, C., Simonelli, A., \& Purgato, N. (2016). Evaluating the Efficacy of Psychodynamic Treatment on a Single Case of Autism. A Qualitative Research. Research in Psychotherapy: Psychopathology, Process and Outcome, 19, 49-57.

Viloca, L., \& Alcácer, B. (2014). La psicoterapia psicoanalítica con personas con trastorno autista. Una revisión histórica [Psychoanalytic Psychotherapy with Autism Spectrum Disorder. An Historical Review]. Temas de Psicoanálisis, 7, 1-29.

Vivanti, G. (2017). Individualizing and Combining Treatments in Autism Spectrum Disorder: Four Elements for a Theory-Driven Research Agenda. Current Directions in Psychological Science, 26(2), 114-119.

Winnicott, D. W. (1975). Through Paediatrics to Psycho-analysis: Collected Papers. Philadelphia, PA, US: Brunner/Mazel. 